\section{RESEARCH AND DEVELOPMENT}

\section{Cambridge Science Park}

CAMBRIDGE is shortly to open a science park. By the autumn the first light industry concentrating on technology advanced products that require a high degree of research and development will be installed on a site to the north of Cambridge.

The scheme, sponsored by Trinity College, emerged after a university committee under Sir Nevill Mott had recommended, in 1969, that science based industry in Cambridge should be expanded.

The report was well received, and Trinity, largely because it had some derelict land to spare, sufficient capital and an enthusiastic bursar who is also a scientist, took on the task of planning and building the park.

When it is completed the 13.5 acre site could house more than 10 companies, although initially Dr John Bradfield, Trinity's bursar, hopes to see about six companies move in. The first of these will be Laser-Scan. Set up by a group of physicists from the Cavendish laboratory, the company specializes in designing and building computer guided laser beams for counting nuclear particles. Other types of industry that Dr Bradfield hopes will be attracted to Cambridge are, for example, companies working on amino acid sequences, thin metal films and any similar science based work that requires intensive research and development.

The object of the science park is a two way exchange of ideas and personnel. Research students, the theory runs, will benefit from contact with high technology industry and the industry will benefit from having some of the best research facilities in the country at hand. Professors will be able to keep in touch by acting as consultants, and Cambridge may gain up to a thousand jobs.

The road to the park's opening has not been entirely smooth, however. The town had to be talked into accepting a development that went against its declared plans, and the college had to cope with rising building costs, but now that the first buildings are going up and service facilities are being put in, $\mathrm{Dr}$ Bradfield is beginning to advertise for clients confident that the scheme is more than an expensive dream.

The park hopes to attract two types of client. One will be the small, new company, specializing in a scientific field, and the other will be the highly specialized research department of large companies or public utilities. Once a company moves into anything resembling large scale production, it will have to move off the park.

The Cambridge Science Park is not unique in Britain. Other universities have close ties to science industries. But it is one of the rare deliberate attempts to create an interchange of research and production experience between universities and industry. In the United States, there are over 80 science parks, one of them more than 3,000 acres in size, but 27 of them are wholly limited to science-based industry of the type that Cambridge wants to attract. Britain offers far fewer opportuities for research ideas to be transferred directly into products.

So far, Trinity has put $£ 200,000$ into the scheme, but Dr Bradfield insists that it is not intended to be a profit making operation. "We hope it will cover its costs in the foreseeable future," he says, "but there are no plans to make a profit. It is after all an academic service."

\section{MEDICINE

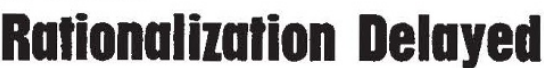

THE University of London's plans for the reorganization of undergraduate teaching in medicine and the biological sciences are in danger of being thwarted by the University Grants Committee. Recently the UGC turned back to the university its list of priorities in this field and the university was asked to reconsider its plans.

Following the publication of the Todd Report in 1968, which recommended that the teaching of medical students and that of biological science undergraduates should be more closely linked, the university after a long period of gestation decided on three schemes to implement these recommendations. The first plan is to place the pre-clinical and clinical medical schools of St Thomas's Hospital, the clinical medical school of Westminster Hospital and the School of Biological Sciences of King's College at one site. The second is to similarly site the pre-clinical parts of the medical schools of the London Hospital and St Bartholomew's Hospital contiguously with the biological sciences department of Queen Mary College. The third scheme is to house the pre-clinical departments of the Royal Free Hospital medical school and of the University College Hospital Medical School and the faculty of medical sciences of University College at a common site.

The University of London in its application to the UGC placed the St Thomas's, Westminster and King's scheme at the top of the list but the University Grants Committee clearly did not favour giving first priority to the most expensive scheme-which is estimated to cost about $£ 6$ milion--and the university has been asked to review its priorities. A spokesman for the St Thomas's, Westminster and King's scheme, said this week that he feared that this might mean that this scheme would now be given a low priority although he felt that there were compelling reasons why this should not be so.

One of the difficulties with this scheme has been the choice of site. After consideration of possible sites both in Covent Garden and on the South Bank, a site at St Thomas's Hospital was finally chosen but this has run into difficulties recently. Contrary to first expectations the site is not the property of St Thomas's Medical School but it is owned by the Department of Health and Social Services. Negotiations are at present taking place over what price, if any, should be paid for the site. A spokesman for the scheme said that the question of evaluating the site should not affect the plans and that it had always been understood that the site would be available.

The other schemes have not had a clear passage either and letters to the press a year or so ago made it clear that the staff at St Bartholomew's Hospital did not favour moving from their present site.

The next move is up to the University of London which has to reply to the UGC's request for a re-evaluation of the scheme.

Whether or not work starts on the proposed centre at St Thomas's Hospital on schedule depends to a great extent on the University's reply.

The present plan is that if the money is granted soon, construction can start in 1975-76 and that the first students can be admitted in the autumn of 1979 .

\section{CONSERVATION}

\section{Friends of the Whales}

Monday sees the start of this year's meeting of the International Whaling Commission. Friends of the Earth and a whole host of other conservationist organizations are again attempting to pressure the commission into imposing a ten year moratorium. Advertisements in The Times next week, and letters signed by conservation organizations world wide and despatched to the heads of state of the commission's member countries are all aimed at achieving the moratorium which was approved by the Stockholm Conference 53 votes to 0 last June.

But the chances of a moratorium are no greater this year than last. Last year's meeting, small though the progress it made was, did at least move the commission some way down the road that the conservationists want it to go, and a further step this year in the form of protecting certain species further and cutting quotas again, could effectively outmanoeuvre the moratorium bid. 